\title{
Distribution Channels in Travel: Using Mystery Shoppers to Understand the Influence of Travel Agency Recommendations
}

Dr Simon Hudson, Associate Professor, University of Calgary, 2500 University Drive NW, Alberta, Canada, T2N 1N4.

Tel: +1 4035473007 Fax: (403) 2847915

Email: shudson@mgmt.ucalgary.ca

Dr Tim Snaith, Global Consultancy Network, 1 Standard Cottages, Grange Road,

Widmer End, Buckinghamshire, England, HP15 6AD

Tel: +44 1494715928

Email: globalconsultancy@ bigfoot.com

Graham A. Miller, Researcher, University of Surrey, Guildford, Surrey, England, GU2 $5 \mathrm{XH}$

Tel: +44 1819921503

Email: ohno.problems@dnet.co.uk

Paul Hudson, Operations Manager Specialist Products, JMC Holidays, 29-31 Elmfield Road, Bromley, Kent, BR1 1LT

Tel: +44 1812768438

Email: paul.hudson@jmc-holidays.co.uk 


\title{
Distribution Channels in Travel: Using Mystery Shoppers to Understand the Influence of Travel Agency Recommendations
}

\begin{abstract}
The objectives of this study were to understand the factors that influence travel agency recommendations in the U.K. The objectives were achieved using a mixture of focus groups, interviews and Mystery Shoppers. Exploration into the process of choosing a holiday showed that the brochure plays an important role for many consumers.

However, for the travel agent the brochure is low priority, and even when the brochure is used, the travel agent often has a considerable amount of influence. Whether or not the agency is vertically integrated has considerable influence on the recommendation process. Based on analysis of the interviews and focus groups, a model was developed, and tested using Mystery Shoppers. Results from investigating 156 travel agents across the U.K. indicate that many travel agents owned by large tour operators, will attempt to push the holidays of their parent company rather than give impartial advise to consumers. Theoretical and practical implications are discussed.
\end{abstract}

\section{INTRODUCTION}

Recommendations are generally viewed as an important type of information considered by consumers during the decision-making process (Howard 1963; Peter and 
Olson 1993). Some researchers have discovered that rather than simply consulting with others (opinion leaders) for opinions or recommendations, consumers often relinquish control of all or part of the decision process to external experts, agents, or surrogates (Solomon 1986). In the travel industry, travel agents represent a key influence in the tourism marketing system (Bitner and Booms, 1982). In addition to helping travelers book reservations and obtain tickets and vouchers, they influence tourism planning decisions and outcomes. Recommendations of which operator to travel with, may be critical to the success of various tourism businesses.

For marketers it is thus critically important to develop an understanding of the factors that might influence travel agent recommendations. However, given the size and the economic impact of the travel intermediary sector of the tourism industry, surprisingly little research has been reported on travel agencies (Kendall and Booms 1989; Goldsmith, Flynn and Bonn 1994). Most previous research has focused on travel agents' consumers, dealing with either their search for information and services (Gitelson and Crompton 1983; Goldsmith et al. 1994; Hsieh and O'Leary 1993; Snepenger et al. 1990; Gilbert and Houghton 1991); or with factors which influence their perceptions of and response to travel agency advertising (Kendall and Booms 1989; Laskey, Seaton and Nicholls 1994). In contrast to these studies which focus on potential tourists, only a few studies have focused on travel agents themselves. One study contrasted travel agents' perceptions of destination attributes with those of their clients (Michie and Sullivan 1990), and another (Contant et al. 1988) examined travel agents and the impact of terrorism on destination recommendations. 
A more recent study by Klenosky and Gitelson (1998) presented a conceptual model describing the recommendation process of travel agents (see Figure 1). They empirically examined the impact on agents' destination recommendations of two factors from the model: trip type and origin. Although the study focused on destination choice as opposed to brochure/tour operator choice (as in this piece of research), it was acknowledged that the role of travel agent recommendations is a neglected but critically important area for study, especially in the current environment of increasing competition and reduced promotional resources. The authors suggest that additional research is needed to develop new models focusing on the other types of recommendations that tourists rely on when making decisions. In particular they suggest one potentially fruitful direction would be to examine the impact on recommendations of specific marketing tactics that are typically directed at travel agents such as sales incentives and commissions. Although these promotional tools are widely used, little is currently known about their differential effectiveness in generating business. Such recommendations (as highlighted in bold in the model) are the focus of this study.

\section{INTEGRATION IN THE UK TRAVEL INDUSTRY}

Expenditure on holidays by the British came to 22.5 billion pounds in 1998 (Mintel 1999), representing a four percent share of all consumer spending. In terms of the type of holiday taken by U.K. consumers when they travel abroad, the package holiday or 
inclusive tour is at the core of the leisure travel industry's business. In 1997, 28 million holidays abroad were taken, of which 15 million were inclusive tours and 13 million were independently organized. The largest three tour operators, Thomson, Airtours, and Thomas Cook, control about $75 \%$ of the market, and each has their own chain of travel agencies. Thomson own 791 Lunn Poly agencies, Airtours control 717 Going Places branches and Thomas Cook have over 700 retail outlets under the Thomas Cook and Carlson brand names (Buckingham 1999).

Travel agents represent a major communication channel for British travelers (Hsieh and O'Leary 1993). 80-90\% of inclusive tours are sold through travel agents, where vertically integrated tour operators are the dominant retailers (Mintel 1999). The Monopolies and Mergers Commission (MMC) have suggested that the traditional mechanism of visiting travel agent, taking away brochures for perusal at home, and returning to the agent to confirm the booking, remains the main retail channel for holidays abroad (MMC 1998). The distribution of inclusive tours has come under close official scrutiny in recent years, and after a recent investigation, the MMC came to the conclusion that the vertical integration of tour operators, charter airlines and major travel agents, did not affect consumer choice adversely.

One practice that was of some concern to the MMC was 'directional selling', which they define as "the sale or attempted sale by a vertically integrated travel agent of the foreign package holidays of its linked tour operator, in preference to the holidays of other operators" (Monopolies and Mergers Commission 1998: pp4). The practice was 
seen as being facilitated by the lack of transparency of ownership links. Independent travel agents and smaller tour operators argue that the vertically integrated travel agents deceive customers by posing as impartial agents when primarily selling their parent company's holidays. However, in their investigation, the MMC found no evidence that directional selling has resulted in less value for money for consumers, and therefore did not rule it to be against the public interest. This has frustrated smaller agents and operators, as well as consumer groups who argue that the practice is anti-competitive and leads to limited and biased choice for the consumer when buying a holiday. They also argue that the practice is more widespread than the MMC or the larger operators prefer to admit. The MMC ruled that vertical integration in the travel business would not compromise consumer choice so long as the agencies clearly spelled out their ultimate ownership (MMC 1998).

\section{OBJECTIVES}

The objectives of this study were to understand the factors that influence travel agency recommendations, and to determine the extent of directional selling in the U.K. To achieve this it was important first to understand the buying process, and in particular, the role of the brochure, for both the trade and consumers.

\section{METHODOLOGY}


The objectives were achieved using a mixture of focus groups, interviews and 'Mystery Shoppers'. Consumer behaviorists are increasingly embracing qualitative techniques and models in order to deal with relevant topics in meaningful and pragmatic ways (Walle 1997). Literature suggests that the sensitive use of qualitative (as opposed to quantitative) techniques, can contribute immeasurably to better understanding of consumer motivations in vacation selection (Hodgson 1993).

The research design had two main stages, and because the results of the first stage determined the structure of the second, the details of each will be discussed in turn.

\section{1) Interviews and Focus Groups}

Five focus group discussions with consumers, lasting between one and one and half-hours, were conducted in various geographical locations. All consumers had been on holiday with a tour operator in the last 2 years and were considering booking a package holiday through a travel agent in the next year. These were complimented by two focus groups with travel agencies counter staff and 6 in-depth interviews with managers. As the research involved two different types of respondent, the focus of the research shifted slightly. For example, travel agents were able to give their perspective on how consumers use brochures and those of other companies, and what influenced their decisions. With 
consumers, the emphasis was shifted to the use of the brochure and how travel agents might influence their final decision on which tour operator to travel with.

\section{Results}

Exploration into the consumer's perspective of the process of choosing a holiday showed that the brochure plays an important role. There appeared to be two distinct routes to booking a holiday using the brochure. One group would have a country or resort in mind and then gather all the relevant brochures. Having looked at the information, they would narrow it down to a few holidays. They would then go into a travel agent with their options to see what is available. The second group - which seemed to be mainly families on a budget - would get all the brochures before consulting the family. They would then look at prices and decide which destinations were possible. They would then either go into the travel agency to book a holiday, or telephone the agent to avoid certain inconveniences such as taking small children to the shop. For them, the travel agent was a key influence on their final decision, especially in choosing which tour operator to travel with.

For the travel agent however, the brochure was found to be a low priority, and often just used as a reference tool. Other factors, such as vertical integration, tour operator commission levels, habit, availability, an efficient View Data system, and pricing, were found to have considerable influence. The key determining factor appeared to be the level of integration, and whether or not the agent was owned by one of the large 
tour operators. Based on analysis of this qualitative data, a model was developed for testing (see Figure 2).

\section{Model Indicating the Role and Influence of the Travel Agent in the U.K.}

The model suggests that the influence of an agency, and therefore its propensity to employ directional selling, will depend upon the request of the customer. Based on the results of the qualitative data collected, four typical scenarios have been proposed:

1) Scenario 1: The customer has one specific holiday from one brochure/operator in mind. Here it is hypothesized that the agent has little influence and will most likely make the booking as requested. However, the agent may attempt to switchsell and direct the customer towards the holiday of their parent company.

2) Scenario 2: The customer has a number of alternatives chosen from different brochures. The authors suggest that the agent will in this case make an attempt to push the holiday of their parent company.

3) Scenario 3: The customer has an amount of money in mind as well as a destination. In this case the agent has strong influence and will recommend the holiday of its parent company.

4) Scenario 4: The customer is looking for a last-minute holiday and calls the agent to see what is available. Again, the agent has strong influence over the decision the customer makes and is likely to employ directional selling of parent company products. 
In the second stage of this research, the above scenarios were tested using mystery shoppers.

\section{2) Mystery Shopping}

'Mystery Shoppers' were used to test travel agent recommendations across the country, with the largest three 'linked' travel agency chains coming under investigation. 52 agencies from Lunn Poly (owned by Thomson), Going Places (Airtours) and Thomas Cook or Carlson (Thomas Cook) were sampled. Figure 2 was operationalised and a mixture of actual visits $(n=36)$ and telephone calls $(n=120)$ were used to get an insight into what happens when potential holidaymakers walk into a travel agent to book a holiday.

Mystery shopping is a form of participant observation where the researcher interacts with the subjects being observed, and stems from the field of cultural anthropology. However, it differs from the original anthropological approach to observation in terms of its structured and systematic format. In the services context, mystery shopping is able to provide information on the service experience as it unfolds (Grove and Fisk 1992), and participant observation helps to develop a richer knowledge of the experiential nature of services. The participant can identify dimensions of the service encounter unlikely to be discerned by a distant or non-participant observer. Concealment of this observation, although raising ethical issues, can ensure that the experience is natural and not contrived for the sake of the observer. 
Mystery shopping is used quite extensively by organizations in financial services, leisure services, retailing, motor dealerships, hotels and catering, passenger transportation, public utilities and government departments. The main benefit for these companies is that it gives them a very clear insight into what is happening when their customers meet their staff. In 1998, mystery shopping was worth over 30 million pounds a year to British marketing research companies. However, published academic research on mystery shopping is limited to a small number of papers that have mainly focused on its use in specific sectors (Wilson 1998). Mystery shopping has been used in banking to find out if the institution is addressing the customer's needs, preferences and priorities (Morrall 1994), but to the authors' knowledge, has not been used by tourism academics for the same purposes.

For the purposes of methodological comparison, a combination of actual visits and telephone calls were used to achieve the study objectives. Time constraints limited the visits to 36 linked travel agents in the London area. However, this itself translates itself to approximately 18 hours of contact time between mystery shoppers and travel agents sales people. In addition, 120 mystery shopping telephone calls were made to the three largest integrated agencies, randomly sampled from an ABTA list of U.K. travel agents. Agents were not warned in advance about the research project, as this would have reduced the effectiveness of the study considerably. Other researchers have recognized that unconcealed observational methods affect the validity of responses (Grove and Fisk 1992). 
Attempts were made to maximize the reliability of the exercise through the use of objective measurement and the careful selection and training of the shoppers. It was ensured that the shoppers matched a customer profile that was appropriate for the scenario that they were being asked to act out. Shoppers were trained, through role-plays, to adopt a neutral rather than an aggressive or defensive approach in the encounter with agents. The training of data collection skills focused on identifying the elements of the service to be observed as well as the retention and recording of the information. Subjectivity was minimized by using rating scales with labels, supported by verbatim comments from shoppers to justify their rating selection. For example researchers had to record how forcibly the agent tried to 'switch sell' on a five-point scale, and then comment on the tactics employed by the agent.

Researchers were given the four different scenarios and a research report form, and conducted the research over a period of two weeks. Each interview took an average of 30 minutes, whilst the telephone calls averaged out at 15 minutes each. The Market Research Society Code of Conduct specifies that mystery shopping should not involve an unreasonable amount of time or expense on behalf of the organization being researched. The researchers in this case only made tentative enquiries (asking about availability) rather than positioning themselves as serious buyers. At the end of the encounter the researchers did not reveal themselves to the travel agent, as sometimes is the practice in North America. Such an approach is viewed by those involved in the U.K. marketing research industry as being too confrontational (Wilson 1998). 


\section{Results}

The results of the mystery shopping exercise have been summarized in Table 1, and the table indicates the level of directional selling employed as well as the level of transparency (agents indicating that they were owned by a tour operator). Chi-square analysis revealed a significant association between the four different scenarios and the level of directional selling employed by the travel agents $\left(\chi^{2}=31.90, \mathrm{df}=6, \mathrm{p}<.001\right)$. Taken as a whole, of the 156 travel agents approached, 95 (60\%) clearly employed directional selling tactics. However, only 9 of the Thomson owned agencies, Lunn Poly, attempted to steer the researchers towards the Thomson product. So aside from Thomson, 86 of the other 104 agencies (82\%) owned by Airtours and Thomas Cook, gave biased advice. $90 \%$ of Going Places agencies pushed the Airtours brand, whilst $75 \%$ of agencies owned by Thomas Cook tried to sell their own brands such as JMC Holidays, Thomas Cook (mainly long haul) and Inspirations.

With the actual visits, for the first scenario none of the agents made an attempt to switch-sell and were happy to check availability as requested. For the second scenario, where the researcher gave the agent 3 options, 7 out of the 9 agents made an attempt to push holidays offered by their parent company. Some of this persuasion was of a subtle nature (the Lunn Poly agents for example gently convinced the researchers that the Thomson holiday was far better value for money than the rest). Going Places, however, used more force in their attempt to push their Airtours holiday. In the third scenario, where the researcher had a sum of money and a destination in mind, every single one of 
the 9 agencies visited employed directional selling tactics. Thomas Cook, Going Places, and Lunn Poly all attempted to sell the holidays run by their parent companies. In the fourth scenario, 6 of the 9 agents asked about late availability pushed holidays belonging to their owners. Surprisingly, two Lunn Poly agencies and one Thomas Cook agency were keen to sell an Airtours holiday! This could possibly be explained by the fact that their parent tour operator just did not have any late availability.

The researchers were also asked to look for evidence of ownership links, either through printed material, or through communication with the agents themselves. Only 1 of the 36 researchers saw a sign indicating ownership (one Going Places agency had small signs on the computer indicating links to Airtours). In addition, only 3 of the agencies informed the mystery shoppers of their ownership ties. In these cases, the ownership was used as a selling tactic - "this is why we can offer you such a good deal on insurance" - said one agent.

With the telephone calls, the Lunn Poly agencies, owned by Thomson, the largest tour operator, were unbiased in the information and recommendations they provided. They all gave similar and very helpful answers to all questions asked of them, and at no time made an attempt to push the client towards a Thomson holiday. Their telephone manner was extremely friendly and professional indicating a high and consistent level of customer service training. In fact $93 \%$ of Lunn Poly agents offered completely unbiased information. Those few that did recommend a Thomson holiday did so in the last two 
scenarios, but this was only 3 from 20 agencies, and could have been based on product knowledge and preference rather than internal pressure to sell the Thomson product.

On the other hand the agencies from Going Places (owned by Airtours) and Thomas Cook or Carlson (linked to Thomas Cook), showed strong evidence of directional selling. In fact $95 \%$ of Going Places travel agents made an attempt to push the Airtours product, whilst not disclosing the identity of their owner. It was only when asked that they revealed (reluctantly) the name of the operator whose holiday they were recommending. Of those agencies linked to Thomas Cook, $80 \%$ employed directional selling tactics. Again, they did not freely admit the connection to the tour operators that they have links with, such as JMC, Thomas Cook Holidays and Inspirations.

\section{IMPLICATIONS}

The results of this study confirm the significance of travel agent recommendations in the decision-making process (Howard 1963; Peter and Olson 1993), as well as supporting the long standing notion that travel agents represent a key influence in the tourism marketing system (Bitner and Booms, 1982). The mystery shopping exercise supported the hypothesized model in Figure 2 for two of the vertically integrated companies, but not for the largest operator, Thomson and their travel agency chain, Lunn Poly. Thomson Travel Group have always claimed publicly that they do not have a sales policy of steering customers towards the purchase of Thomson Holidays, and this survey 
supported their claims. This contradicts results from a previous consumer group survey (Goldsmith 1997) that suggested Thomson were just as guilty of directional selling as their competitors.

Customers entering a travel agent linked to Airtours and Thomas Cook, however, are likely to receive biased recommendations, and a distinct lack of choice. This means that these travel agents are much more likely to put the interests of large tour operators before the interests of consumers. Ultimately this could mean a consumer ending up on a package holiday unsuited to their needs, as well as being anti-competitive for the industry. Supporters of directional selling (and some have argued that it makes eminent business sense to control the chain of supply) suggest that the real issue is whether the consumer is being left to believe they are getting the best independent advice to suit their holiday needs. The mystery shoppers used for this piece of research did not believe they were receiving such advice except from the Lunn Poly agents.

The results also showed that the vertically integrated companies are not complying with Office of Fair Trading demands to make their ownership links more transparent. Both the vertically integrated companies that employed directional selling failed to disclose their ownership ties, and some were very reluctant to do so when asked. The Monopolies and Mergers Commission suggest that the lack of transparency means that consumers shop around less for holidays, with the result that there is less competitive pressure on travel agents. Consumers are therefore likely to get less value for money (MMC 1998). 
Methodologically, there were a few subtle differences between the mystery shopping visits as opposed to the telephone calls. For the visits in the first scenario, none of the agents attempted to switch-sell, but 12 of the 30 agents called by phone made an attempt to change the caller's plans. Perhaps in person, the travel agent saw more of an opportunity to close a sale and therefore did not want to confuse the customer. When they did attempt to direct the researcher towards their tour operator, the agents visited in person employed much more subtle tactics, often spending considerable time explaining why the customer should chose another product. This was the case even for the Lunn Poly agents who were reported to use less force than the other two chains. However, when called by telephone, the Lunn Poly agents were completely unbiased, and their telephone manner and professionalism indicated a high and consistent level of customer 'tele-sales' service training.

The study has also shown the advantages of direct observational data collection methods in the tourism sector. Mystery shopping will continue to grow as a result of the increasing emphasis being put on service quality and service standards (Wilson 1988). To date, the distinctive capabilities of observational methodologies for investigating services phenomena have not been widely recognized. Unfortunately, direct observation can be costly, time consuming and sometimes infeasible. In this study, mystery shopping, whilst being extremely effective, was very time consuming. Concealed observation also raises concerns over the research's ethical nature. Whilst reducing the risk of 'unnatural' subject behavior, concealed observation represents an unannounced intrusion, and may 
violate rights to privacy. In this study, the authors were sensitive to the ethical ramifications of mystery shopping, but recognized that to glean the most accurate information, it was necessary to employ a concealed observational approach.

\section{CONCLUSION}

In a mature package holiday market, shareholder demands for constantlyimproved profits have left the vertically integrated tour operators with three choices. They can increase prices, but risk losing market share. Alternatively they can cut prices to gain market share, at the risk of also cutting earnings and perhaps sparking a price war. Another option is to ensure those who sell holidays sell their holidays rather than competitors, and that means buying distribution or influencing travel agents. For the time being it is clear that the big tour operators have chosen the latter tactic. This research has shown that two of the three largest vertically integrated travel companies in the U.K. actively employ directional selling tactics. It is not the purpose of this paper to suggest that this has an adverse affect on the consumer, and the travel industry in general, but the issue clearly requires further debate. More importantly, the study, and its use of mystery shopping as a powerful research technique, has highlighted the critical role that travel agents play in the decision process of consumers. Nearly 20 years ago Bitner and Booms (1982) observed that retail travel agents played a pivotal role in the tourism distribution channel. Despite the impact of technology and the advent of on-line bookings, these observations still stand. 


\section{REFERENCES}

Bitner, M.J. and Booms, B.H. (1982). Trends in Travel and Tourism Marketing: The Changing Structure of Distribution Channels, Journal of Travel Research, 20 (4): 39-44.

Buckingham, L. (1999). Airtours Goes Back to the Singles Market, The Guardian, June 11: 27.

Contant, J.S., Clark, T., Burnett, J.J., and Zank, G. (1988). Terrorism and Travel: Managing the Unmanageable, Journal of Travel Research, 26 (4): 16-20.

Gilbert, D.C., and Houghton, P. (1991). An Exploratory Investigation of Format, Design, and Use of U.K. Tour Operators' Brochures, Journal of Travel Research, 30 (2): 20-25.

Gitelson, R.J. and Crompton, J.L. (1983). The Planning Horizons and Sources of Information Used by Pleasure Vacationers, Journal of Travel Research, 21 (3): 2-7.

Goldsmith, N. (1997). Who's Taking You on Holiday? Which? May: 8-10. 
Goldsmith, R.E., Flynn, L.R., and Bonn, M. (1994). An Empirical Study of Heavy Users of Travel Agencies, Journal of Travel Research, 33 (1): 38-43.

Grove, S.J. and Fisk, R. (1992). Observational Data Collection Methods for Services Marketing: An Overview, Journal of the Academy of Marketing Science, 20 (3): 217-224.

Hodgson, P. (1993). Tour Operator Brochure Design Research Revisited, Journal of Travel Research, 32 (1): 50-52.

Hsieh, S., and O'Leary, J.T. (1993). Communication Channels to Segment Pleasure Travelers, Journal of Travel and Tourism Marketing, 2 (2\&3): 57-75.

Howard, J.A. (1963). Marketing Management ( $2^{\text {nd }}$ ed.). Homewood IL: Irwin Publishing.

Kendall, K.W., and Booms, B.H. (1989). Consumer Perceptions of Travel Agencies:

Communications, Images, Needs, and Expectations, Journal of Travel Research, 27 (4): 29-37.

Klenosky, D.B., and Gitelson, R.E. (1998). Travel Agents' Destination Recommendations, Annals of Tourism Research, 25 (3): 661-674.

Laskey, H.A., Seaton, B., and Nicholls, J.A. (1994). Effects of Strategy and Pictures in Travel Agency Advertising, Journal of Travel Research, 32 (4): 13-19. 
Michie, D.A., and Sullivan, G.L. (1990). The Role(s) of the International Travel Agent in the Travel Decision Process of Client Families, Journal of Travel Research, 29 (2) 30-38.

Mintel. (1999). Inclusive Tours, Mintel International Group Limited: London.

Monopolies and Mergers Commission. (1998). Foreign Package Holidays. HMSO.

Morrall, K. (1994). Mystery Shopping Tests Service and Compliance, Bank Marketing, 26 (2): 13-23.

Peter, J.P.P., and Olson, J.C. (1993). Consumer Behavior and Marketing Strategy, Homewood IL: Irwin.

Snepenger, D., Meged, K., Snelling, M., and Worrall, K. (1990). Information Search Strategies by Destination-Naive Tourists, Journal of Travel Research, 29 (1): 13-16.

Solomon, M.R. (1986). The Missing Link: Surrogate Consumers in the Marketing Chain, Journal of Marketing, 50 (4): 208-218.

Walle, A.H. (1997). Quantitative Versus Qualitative Research, Annals of Tourism Research, 24 (3): 524-536. 
Wilson, A.M. (1998). The Use of Mystery Shopping in the Measurement of Service Delivery, The Service Industries Journal, 18 (3): 148-163. 


\section{Figure 1: Conceptual Model of the Process and Factors Influencing Travel Agent's Destination Recommendations (Klenosky \& Gitelson, 1998)}

\section{* Focus of this study}

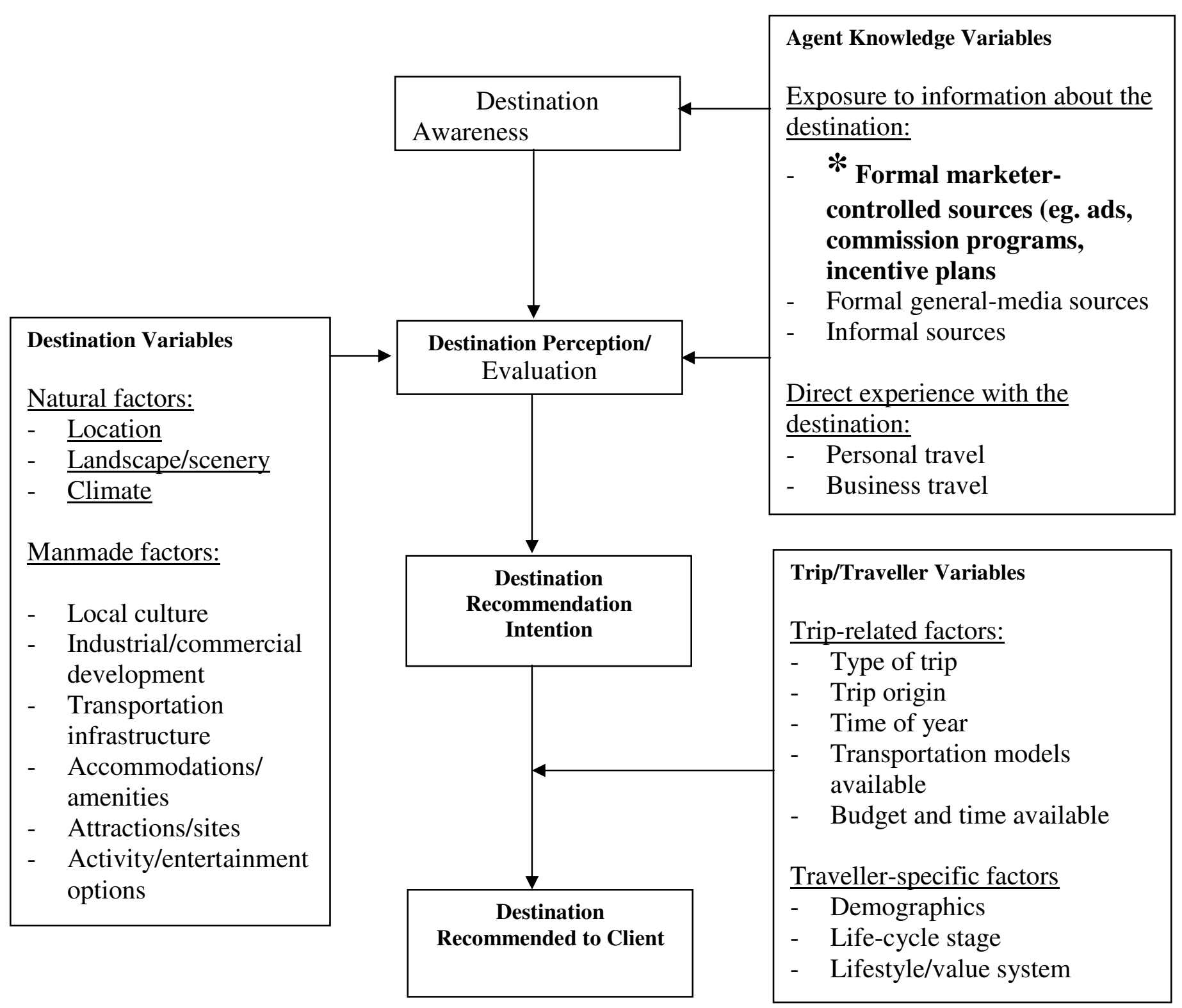




\section{Figure 2: Model Indicating the Role and Influence of the Travel Agent in the UK}

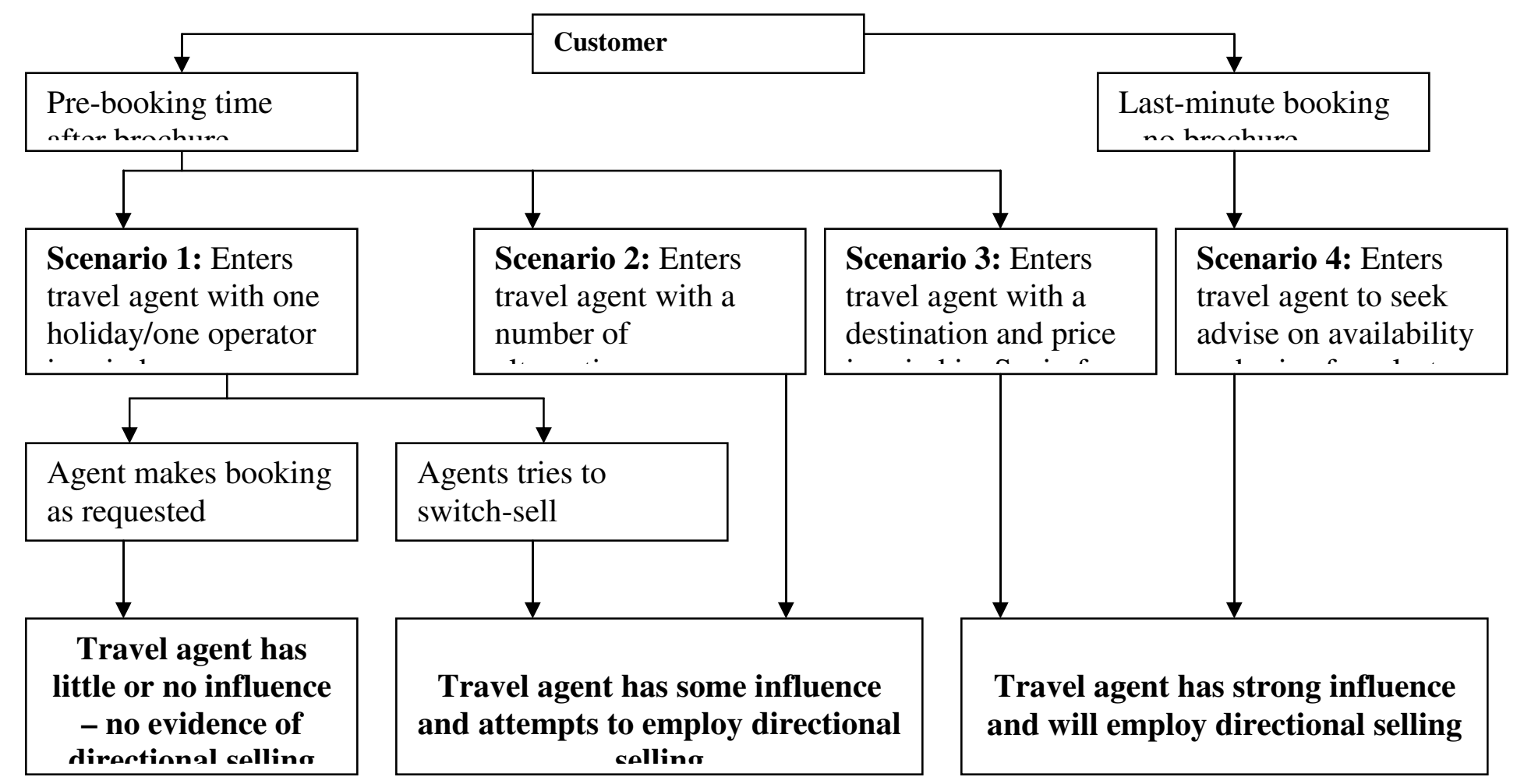




\section{Table 1: Results of Mystery Shopping Exercise}

\begin{tabular}{|c|c|c|c|c|c|c|}
\hline \multirow{2}{*}{$\begin{array}{l}\text { MYSTERY SHOPPING SCENARIOS } \\
156 \text { calls/visits were made to agencies } \\
\text { around the UK spread evenly amongst } \\
\text { the } 3 \text { largest linked agencies ( } 52 \text { each) } \\
\text { They were asked the following } 4 \\
\text { questions (13 agents per question): }\end{array}$} & \multicolumn{3}{|c|}{$\begin{array}{l}\% \text { Of agents that tried to } \\
\text { persuade researchers to } \\
\text { travel with their parent } \\
\text { company/linked operators } \\
\text { instead of others }\end{array}$} & \multicolumn{3}{|c|}{$\begin{array}{l}\text { If so, did they make it clear } \\
\text { that they were owned by the } \\
\text { parent company? }\end{array}$} \\
\hline & $\begin{array}{l}\text { Lunn } \\
\text { Poly }\end{array}$ & $\begin{array}{l}\text { Going } \\
\text { Places }\end{array}$ & $\begin{array}{l}\text { Thomas } \\
\text { Cook or } \\
\text { Carlson }\end{array}$ & $\begin{array}{l}\text { Lunn } \\
\text { Poly }\end{array}$ & $\begin{array}{l}\text { Going } \\
\text { Places }\end{array}$ & $\begin{array}{l}\text { Thom } \\
\text { as } \\
\text { Cook } \\
\text { or } \\
\text { Carlso } \\
\text { n }\end{array}$ \\
\hline $\begin{array}{l}\text { TRAVEL AGENT OWNED } \\
\text { BY: }\end{array}$ & Thomson & Airtours & $\begin{array}{l}\text { Thomas } \\
\text { Cook }\end{array}$ & $\begin{array}{l}\text { Thomso } \\
\text { n }\end{array}$ & Airtours & $\begin{array}{l}\text { Thoma } \\
\text { s } \\
\text { Cook }\end{array}$ \\
\hline $\begin{array}{l}\text { 1. Travel agency was asked about the } \\
\text { availability of a Cosmos holiday in } \\
\text { Majorca. A hotel was chosen where } \\
\text { Thomson/Airtours/Thomas Cook go } \\
\text { (Cosmos have no travel agencies) }\end{array}$ & $\begin{array}{l}0 / 13 \\
0 \%\end{array}$ & $\begin{array}{l}8 / 13 \\
61 \%\end{array}$ & $4 / 13$ & No & $\begin{array}{l}\text { No, only } \\
\text { when } \\
\text { asked, } \\
\text { and } \\
\text { reluctant } \\
\text { ly }\end{array}$ & $\begin{array}{l}\text { No, } \\
\text { only } \\
\text { when } \\
\text { asked }\end{array}$ \\
\hline $\begin{array}{l}\text { 2. Travel agency was asked about the } \\
\text { availability of two specific holidays } \\
\text { from brochures, one a Cosmos holiday } \\
\text { and the other a } \\
\text { Thomson/Airtours/Thomas Cook } \\
\text { holiday }\end{array}$ & $\begin{array}{l}2 / 13 \\
15 \%\end{array}$ & $\begin{array}{l}13 / 13 \\
100 \%\end{array}$ & $\begin{array}{l}10 / 13 \\
77 \%\end{array}$ & No & $\begin{array}{l}\text { Sign on } \\
\text { compute } \\
\mathrm{r} \text { in } 1 \\
\text { agency }\end{array}$ & No \\
\hline $\begin{array}{l}\text { 3. Travel agency was asked about the } \\
\text { availability of a specific hotel and resort } \\
\text { chosen from the brochures (where all the } \\
\text { major operators go) }\end{array}$ & $5 / 13$ & $13 / 13$ & $13 / 13$ & No & No & No \\
\hline $\begin{array}{l}\text { 4. Travel agency was asked about the } \\
\text { general availability in the Canary Islands } \\
\text { for the following week }\end{array}$ & $15 \%$ & $100 \%$ & $92 \%$ & No & No & No \\
\hline $\begin{array}{l}\text { TOTAL \% FOR EACH AGENT } \\
\text { EMPLOYING DIRECTIONAL } \\
\text { SELLING }(n=52)\end{array}$ & $\begin{array}{l}9 / 52 \\
17.3 \%\end{array}$ & $\begin{array}{l}47 / 52 \\
90 \%\end{array}$ & $75 \%$ & & & \\
\hline
\end{tabular}

